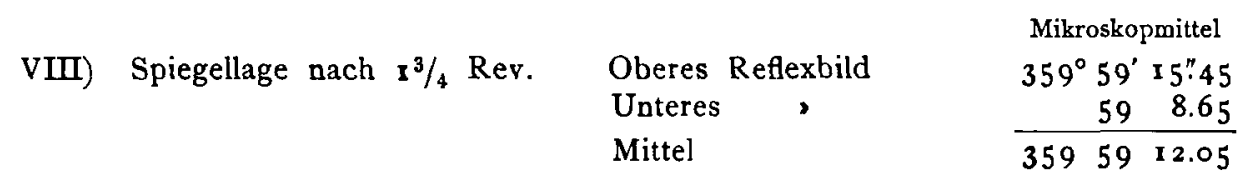

Ich erhalte also hieraus die folgenden vier unabhängigen Bestimmungen des Zenithpunktes:

$$
\begin{array}{lll}
\frac{\mathrm{I}+\mathrm{III}}{2}=359^{\circ} 59^{\prime} 16^{\prime \prime} 65 & \frac{\mathrm{V}+\mathrm{VII}}{2}=359^{\circ} 59^{\prime} \mathrm{I} 6^{\prime \prime} 48 \\
\frac{\mathrm{II}+\mathrm{IV}}{2}=3595916.23 & \frac{\mathrm{VI}+\mathrm{VIII}}{2}=35959 \times 5.90
\end{array}
$$

Das Gesammtmittel $359^{\circ} 59^{\prime} 16 !_{3}$ I stimmt nahe mit dem an diesem Abend aus $\pi$ Pegasi, ro Lacertae, $\eta$ Pegasi und $\varphi=50^{\circ} 43^{\prime} 45^{\prime}$. folgenden Werthe $359^{\circ} 59^{\prime} 16 . " 1$; der w. F. des ersteren, \pm 0.11 , wird durch die verbesserte Beleuchtungseinrichtung in die erforderlichen engeren Grenzen herabgesetzt werden.

Bonn 1896 September.

\title{
Fr. Deichmuiller.
}

\section{Note on Prof. Bruns' Formulae \\ for the Correction of Heliometer Observations for Refraction.}

\section{By Harold facoby.}

The Saxon Academy has published recently an admirable memoir by Dr. Bruno Peter on the results of his parallax observations made with the Repsold heliometer of the Leipzig observatory. Dr. Peter gives a set of formulae which have been deduced by Prof. Bruns for computing the effect of refraction upon measured distances. The demonstration of these formulae is not given, but it is stated that a demonstration is to be published elsewhere. Pending the publication of this demonstration, the following considerations may be of interest.

Prof. Bruns' formulae are as follows:

$$
\begin{aligned}
2 S & =2 s+\frac{1-s_{0}{ }^{2}}{s_{0}\left(1+s_{0}\right)}(2 s)-\frac{\left(s_{0} s^{1}\right)}{4 s_{0}{ }^{5}}(2 s)^{3} \\
1-s_{0}{ }^{2} & =c+d \cos ^{2} N \\
\left(s_{0} s^{1}\right) & =\alpha \sin ^{4} N+\beta \cos ^{2} N \sin ^{2} N+\gamma \cos ^{4} N
\end{aligned}
$$

In these formulae $N$ is the angle between the great circle joining the two stars and a vertical circle passing through the point midway between them. $2 S$ and $2 S$ are the true and apparent distance between the stars. $c, d, \alpha$, $\beta$, and $\gamma$ are constants which have been tabulated by Dr. Peter. They depend only on the true zenith distance of the point midway between the two stars, and are therefore given with this zenith distance as argument. The table extends to the zenith distance $74^{\circ}$ only, so that the following remarks are limited to observations taken within that distance of the zenith.

The well-known formula of Bessel for refraction in distance is :

$$
\sigma-s=s x\left(\operatorname{tg}^{2} \zeta \cos ^{2} N+1\right)
$$

The formula, as Bessel himself pointed out, is more correctly written as follows:

$$
\sigma-s=s x\left(\operatorname{tg}^{2} \zeta \cos ^{2} N+1\right)+s(k-x)
$$

This formula of Bessel being practically correct within terms depending on the third power of the distance, we ought to be able to obtain the relation between Bessel's constants $x$ and $k$ and Bruns' constants $c$ and $d$. This can be done easily, if we remember that Bessel's and Bruns' formulae ought to give the same results for the term depending on the first power of the distance for all values of $N$. If we put in both formulae:

$$
\cos ^{2} N=0 \text {, }
$$

we get on the assumption that the term in question should be the same from both:

Similarly if we put :

$$
c=\frac{k(k+2)}{(\mathbf{I}+k)^{2}} .
$$

we get:

$$
\cos ^{2} N=\mathbf{I}
$$

$$
c+d=\frac{K(K+2)}{(\mathrm{r}+K)^{2}}
$$

where, for brevity, I have put:

$$
K=x \operatorname{tg}^{2} \zeta+k .
$$

$K$ and $k$ being very small quantities, we may write instead of these formulae:

$$
\begin{aligned}
c & =2 k-3 k^{2} \\
c+d & =2 K-3 K^{2}
\end{aligned}
$$

These simple formulae express the relation between Bruns' constants $c$ and $d$, and Bessel's constants $k$ and $x$, aiways on the assumption that the two formulae should give the same results for the term depending on the first power of the distance.

I have computed the constants $c$ and $d$ by means of these formulae, taking Bessel's constants from the ordinary refraction table. The results are as follows, for various zenith distances: 


\begin{tabular}{ccc} 
Zenith- & \multicolumn{2}{c}{ Constant $c$} \\
distance & Formula & Peter \\
$0^{\circ}$ & 0.0005596 & 0.0005598 \\
45 & 0.0005588 & 0.0005590 \\
60 & 0.0005571 & 0.0005575 \\
74 & 0.0005500 & 0.0005511
\end{tabular}

It appears from the above little table, which gives the values computed from the above formulae, Peter's values, and the ratio between them, that within the limit of $74^{\circ}$ zenith distance the Bruns' formula gives practically the same result for the term depending on the first power of the distance as Bessel's formula. By multiplying the Besselian refraction constant by 1.0008 , the agreement of the two formulae would be rendered still closer. But the Besselian formula has the advantage of being simpler and easier to use than that of Prof. Bruns, especially as the

\begin{tabular}{cccc}
\multicolumn{2}{c}{ Constant $d$ Peter } & $c$ & $d$ \\
Formula & Ratio & \\
0.0000000 & 0.0000000 & 1.0004 & 1.0000 \\
0.0005554 & 0.0005554 & 1.0004 & 1.0000 \\
0.0016506 & 0.0016513 & 1.0007 & 1.0004 \\
0.0064291 & 0.0064374 & 1.0021 & 1.0012
\end{tabular}

differences between the successive values of the constant $d$ are very large and variable in Dr. Peter's table.

Some five or six years ago I made an investigation of differential refraction for heliometer measures. The results were published in the Monthly Notices (Vol. $5 \mathrm{r}$, p. 78 ), and an error that I subsequently found in my work was also published (Vol. 51, p. 575). If we indicate the term in $s^{3}$ by:

$$
B s^{3} \times \text { 1 }^{-9} \text {, }
$$

where $s$ is the distance, then the values of the coefficient $B$ which I obtained are contained in the following little table:

\begin{tabular}{|c|c|c|c|c|c|c|c|c|c|c|}
\hline \multirow{2}{*}{\multicolumn{2}{|c|}{$\begin{array}{c}\pi-q \\
\text { or } N\end{array}$}} & \multicolumn{6}{|c|}{$\log \operatorname{tg}^{2} \zeta$} & \multirow{2}{*}{ I.4 } & \multirow{2}{*}{\multicolumn{2}{|c|}{$\begin{array}{l}\pi-q \\
\text { or } N\end{array}$}} \\
\hline & & 0.5 & 0.9 & I.O & I.I & - $\quad 1.2$ & I. 3 & & & \\
\hline $180^{\circ}$ & $0^{\circ}$ & 0.00003 & 0.00013 & 0.00019 & 0.00029 & 0.00039 & 0.00060 & 0.00088 & $180^{\circ}$ & $360^{\circ}$ \\
\hline 170 & Io & 3 & I 2 & I 9 & $\quad 28$ & 37 & 56 & 82 & 190 & $35^{\circ}$ \\
\hline 160 & 20 & 2 & Io & 17 & 24 & 30 & 47 & 69 & 200 & 340 \\
\hline 150 & 30 & 1 & 8 & I 2 & 17 & 23 & 34 & 49 & $2 \mathrm{IO}$ & $33^{\circ}$ \\
\hline 140 & 40 & I & 5 & 7 & I I & 14 & 2 I & 31 & 220 & 320 \\
\hline 130 & 50 & $\mathbf{I}$ & 3 & 4 & 5 & 7 & I I & 16 & 230 & 310 \\
\hline I 20 & 60 & 0 & $\mathbf{I}$ & 2 & 3 & 3 & 4 & 6 & 240 & 300 \\
\hline 110 & 70 & o & 0 & I & I & $\mathbf{I}$ & 1 & 2 & 250 & 290 \\
\hline 100 & 80 & 0 & 0 & 0 & 0 & 0 & 0 & 0 & 260 & 280 \\
\hline 90 & 90 & 0 & 0 & 0 & 0 & 0 & 0 & o & 270 & 270 \\
\hline
\end{tabular}

The square of the tangent of the zenith distance is used as an argument, because interpolation is facilitated thereby, and because this quantity must be computed any way, if the Besselian formula is used for the term in $s$.

Computing by this table for a zenith distance of $74^{\circ}$, and putting $N=0^{\circ}, s=7500^{\circ}$, I find for the term in $s^{3}$, the value $0^{n} \mathrm{II}$, agreeing within $0^{\prime \prime} \circ \mathrm{I}$ with the value given by Dr. Peter.

New York, Columbia College, I 896 October.
The coefficient of $s^{3}$, given in my table is computed by the formula :

$$
B=n\left[\cos ^{4} N+\cos ^{2} N \operatorname{ctg}^{2} \zeta\right]
$$

The corresponding coefficient in the formula of Bruns is at once seen to be of a similar form, if we omit the term $\alpha \sin ^{4} N$

which is stated by Dr. Peter to be inappreciable.

\section{Harold Facoby.}

\section{Bemerkung zu dem vorstehenden Aufsatz.}

In der angefuhrten Peter'schen Abhandlung ist ausdrücklich angegeben, dass die dort gebrauchten Refractionen auf einer an die Bessel'schen Tafeln angeschlossenen Formel von Th. von Oppolzer beruhen. Die in A.N. Nr. 2135 mitgetheilte Vergleichung lässt erkennen, dass die Unterschiede zwischen Tafel und Formel, von der Nähe des Horizonts abgesehen, praktisch belanglos sind. Das Gleiche gilt daher auch ohne besondere Untersuchung für Differentialrefractionen aller Art, sobald man nur richtig rechnet.

Dass die von Bessel für das erste Glied bei Heliometermessungen gegebene Formel wegen der Einfuhrung gewisser erlaubter Vernachlässigungen für die directe Rech- nung etwas bequemer ist, als die von mir beibehaltene strenge Gestalt, gebe ich gern zu, ebenso auch, dass das in der Peter'schen Abhandlung angefübrte Tafelskelett mehrfach grosse und für den unmittelbaren Gebrauch unbequeme Differenzen aufweist. Diese Umstände werden aber belanglos, sobald man - wie es sich für den laufenden Gebrauch doch wohl von selbst versteht _- alles aus Hülfstafeln mit hinreichend engem Intervall entnimmt.

Schliesslich bemerke ich noch, dass das a. a. O. Mit. getheilte nur ein Bruchstück aus einer zusammenhängenden Ausarbeitung über das Capitel »Refraction * ist, die ich mir schon vor zehn Jahren, theilweise sogar noch früher, für 